\title{
Analysis of Peptides and Proteins Affinity-Bound to Iron Oxide Nanoparticles by MALDI MS
}

\author{
Sarah Y. Chang \\ Department of Chemistry, Tunghai University, Taichung, Taiwan \\ Nan-Yan Zheng and Chee-Shan Chen \\ Department of Applied Chemistry, Chaoyang University of Technology, Taichung, Taiwan \\ Cheng-Dah Chen, Ying-Yi Chen, and C. R. Cris Wang \\ Department of Chemistry and Biochemistry, National Chung Cheng University, Chia-Yi, Taiwan
}

\begin{abstract}
Iron oxide nanoparticles modified with oleate have been employed for the extraction of peptides and proteins from aqueous solution before matrix-assisted laser desorption/ionization (MALDI) mass spectrometric (MS) analysis. Adsorption of peptides and proteins onto the nanoparticles were mainly through electrostatic attraction and hydrophobic interaction. The analyte-adsorbed iron oxide nanoparticles could be efficiently collected from solution using a magnet. No elution step was needed. With this preconcentration strategy, the lowest detectable concentration of angiotensin I, insulin, and myoglobin in $500 \mu \mathrm{L}$ of aqueous solution were $0.1 \mathrm{nM}, 0.1 \mathrm{nM}$, and $10.0 \mathrm{nM}$, respectively. In addition, the nanoparticles could extract the analytes from solution with a high content of salt and surfactant, thus eliminating suppression effect during MALDI MS analysis. This method was successfully applied to concentrate the tryptic digest products of cytochrome $c$. In addition, the tryptic digestion of cytochrome $c$ can be directly conducted on the iron oxide nanoparticles. (J Am Soc Mass Spectrom 2007, 18, 910-918) @ 2007 American Society for Mass Spectrometry
\end{abstract}

$\mathrm{M}$ atrix-assisted laser desorption/ionization (MALDI) mass spectrometry (MS) has become a routine analytical tool to determine the molecular mass of biomolecules [1-3]. However, samples containing excessive amounts of salts, surfactants, or other contaminations suffer from ionization suppression and adduct formation $[4,5]$. This limits the application of MALDI technique. Therefore, a simple and selective procedure for extraction and concentration of analyte from complex samples before MALDI MS is required.

Various methods have been developed to isolate the analyte from complex sample matrix. In surface-enhanced laser desorption/ionization (SELDI), the sample target played an active role in the extraction, purification, or concentration of the analyte of interest [6-9]. The target surface was derivatized for the selective retention of analyte while removing interferences through on-target washing. Several surface derivatizations have been designed to extract and concentrate the analyte through hydrophobic interaction [10,11], ionic interaction $[12,13]$, or immunoaffinity $[14,15]$. How-

Published online March 28, 2007

Address reprint requests to Dr. S. Y. Chang, Department of Chemistry, Tunghai University, Taichung 407, Taiwan. E-mail: ychang@thu.edu.tw ever, the sensitivity improvement was limited by the number of binding sites on the target. In another approach, the so-called surface-enhanced affinity capture (SEAC), micrometer-sized beads made for chromatography column were used to capture peptides and proteins from sample solution [16]. Various types of beads have been used, which include reverse-phase chromatographic beads $[17,18]$ and immobilized metal ion beads [19-21]. To speed up the collection of analyteadsorbed beads from sample solution, magnetic particles, which can be simply collected using a magnet, were developed [22-24]. After collection, the microbeads were washed and placed on sample target, followed by analyzing with MALDI MS. Unfortunately, the presence of those particles on the sample target was reported to cause decrease in mass accuracy and resolution $[25,26]$.

Recently, nanoparticles have become interesting probes for the separation of analyte from sample solution because of their high surface area-to-volume ratio. In addition, the interference of nanoparticles during the laser desorption/ionization process may not exist because of the smallness of the particles. Previously, $\mathrm{C}_{18}$ functionalized silica nanoparticles have been utilized for hydrophobic interactions to extract peptides from acetonitrile, followed by liquid atmospheric pressure 
MALDI MS analysis [27]. Gold-modified magnetic nanoparticles [28] and diamond [29] were also used to selectively concentrate positively-charged proteins through electrostatic interaction. The adsorbed proteins were then eluted by adding MALDI matrix solution, such as sinapinic acid (SA) and $\alpha$-cyano-4-hydroxycinnamic acid (CHCA). An aliquot of the mixed solution was deposited on sample target for acquisition of mass spectra. This method allows the MALDI MS detection of low concentration of proteins in complex matrix solution. Other types of nanoparticles have also been used to capture the analytes of interest, such as phosphopeptides [30,31], antigen [32-34], oligonucleotides [35, 36], aminothiol [37], protein [38, 39], and bacteria $[40,41]$. Among the nanoparticles used, carbon nanotube [38], Nile red-adsorbed gold [37], and $\mathrm{TiO}_{2}$-coated magnetic nanoparticles [30] were not only employed as affinity probes but also as matrices.

The amount of analytes adsorbed onto the nanoparticles increases with decreasing the diameter of nanoparticles [42]. However,ëcollectionëofëtheënanoparticles with diameter smaller than $10 \mathrm{~nm}$ by centrifugation was not easy. Additionally, the adsorbed analytes may desorb from the surface of nanoparticles during centrifugation. Magnetic nanoparticles can be easily collected by using an external magnet. Our goal in this study was to examine whether the iron oxide nanoparticles (IONPs) can be used to capture the peptides and proteins in dilute and complex sample solution. The surfaces of the iron oxide nanoparticles were modified with oleate, which contains a long carbon chain and an anionic carboxylate group. The oleate modified IONPs can attract positively-charged proteins or peptides through electrostatic attraction and hydrophobic interaction. Then a magnet can be used to isolate the IONPs quickly from the sample solution. The ability of the IONPs to act as affinity probes for charged species was evaluated. The applicability of the method to the peptide residue from the tryptic digest products of cytochrome $c$ was also demonstrated. In addition, the tryptic digestion of cytochrome $c$ can be directly conducted on the IONPs.

\section{Experimental}

\section{Chemicals}

Angiotensin I, insulin (from bovine pancreas), cytochrome $c$ (from horse heart), myoglobin (from equine skeletal muscle), sinapinic acid (SA), ammonium bicarbonate, sodium phosphate dibasic, and sodium oleate were purchased from Sigma (St. Louis, MO). $\alpha$-Cyano4-hydroxycinnamic acid (CHCA) was obtained from Aldrich (Milwaukee, WI). Ferrous chloride tetrahydrate was purchased from Fluka (Buchs, Switzerland). Iron(III) chloride anhydrous was purchased from Riedel-de Haën (Seelze, German). Hydrochloric Acid was purchased from J. T. Baker (Phillipsburg, NJ). Sodium hydroxide was purchased from Hayashi Pure
Chemical Industries Ltd. (Osaka, Japan). Trypsin was from Promega (Madison, WI). All chemicals were used as received without further purification. All other chemicals were of reagent grade. Water purified with a Barnstead NANOpure system (Dubuque, IA) was used for all solutions.

\section{Preparation of IONPs and Surface Modification}

Iron oxide nanoparticles in aqueous solution were preparedëbyëëwell-knownëcoprecipitationëmethodë 43,ë44]. Briefly, a reactant solution was prepared by mixing $0.2 \mathrm{~g} \mathrm{FeCl}{ }_{2} 4 \mathrm{H}_{2} \mathrm{O}$ and $0.34 \mathrm{~g} \mathrm{FeCl}_{3}$ into $1.7 \mathrm{~mL}$ of deaerated $0.2 \mathrm{M} \mathrm{HCl}$ solution. An aliquot of $160 \mu \mathrm{L}$ of resulting reactant solution was dropwise added into $200 \mathrm{~mL}$ aqueous $\mathrm{NaOH}$ solution $(0.01 \mathrm{M})$ under vigorous stirring. The solution mixture was stirred for $30 \mathrm{~min}$ until the black precipitates of iron oxide nanoparticles formed. Thus prepared iron oxide nanoparticles were then separated from the solution by using a magnet and the supernatant was removed from the precipitate by decantation. The iron oxide nanoparticles were redispersed by adding $50 \mathrm{~mL}$ deoxygenated deionized water and the solution was further centrifuged (8000 rpm and $10 \mathrm{~min}$ ) to obtain flocculates. This purification cycle was repeated three times to remove excess salts. The redispersion of the final flocculates was done by adding 0.01 $\mathrm{M} \mathrm{HCl}$ aqueous solution (typically $15 \mathrm{~mL}$ ) with stir to convert the anionic charges on the nanoparticles into positive. The resulting cationic colloidal particles were stabilized because of the positive surface charges, and the solution appeared black.

The surface modification of the IONPs was then conducted to attach anionic carboxylate groups onto iron oxide nanoparticles following the previously reportedë procedureë [45,ë 46].ë Thisë procedureë isë quite straightforward: dilute the previously obtained cationic iron oxide nanoparticles by dissolving $2 \mathrm{~mL}$ into $8 \mathrm{~mL}$ $\mathrm{HCl}$ solution $(0.01 \mathrm{M})$. Then, $2 \mathrm{~mL}$ sodium oleate solution $(0.033 \mathrm{M})$ was added dropwise into the concentration adjusted iron oxide nanoparticles aqueous solution which was kept at $80{ }^{\circ} \mathrm{C}$ with mild stir. The surface modification reaction was allowed to complete at least $10 \mathrm{~min}$. A centrifugation followed by redispersion was then performed to remove the excess amount of oleates. Thus prepared IONPs solution was centrifuged by $12,000 \mathrm{rpm}$ for $10 \mathrm{~min}$. The flocculates at the bottom of ultracentrifugation vial were separated from the excess amount of sodium oleates by decanting the upper portion. The flocculates were redispersed into deionized water and then the final solution was adjusted to give its $\mathrm{pH}$ value close to 5 .

\section{Characterization of IONPS}

The shape and size distribution of IONPs were characterized by transmission electron microscope (TEM) using TEM (JEOL, Tokyo, Japan) at an accelerating $200 \mathrm{kV}$. TEM samples were prepared by dipping 200 mesh 
Formvar coated copper grid into the IONP aqueous solution. The iron content in the IONP solution was measured by an atomic absorption spectrometry (AAS). For such measurements, $10 \mu \mathrm{L}$ of IONP solution mixed with $990 \mu \mathrm{L}$ of $12 \mathrm{M} \mathrm{HCl}$ to convert IONPs into $\mathrm{Fe}^{2+}$ solution followed by AAS quantitative analysis (AA3110; Perkin Elmer, Wellesley, MA). The dissolution and $\mathrm{Fe}^{3+} / \mathrm{Fe}^{2+}$ transformation required $30 \mathrm{~min}$. The AAS measurements indicated that the IONPs suspension contained $31.6 \mathrm{mM} \mathrm{Fe}(\mathrm{II}) / \mathrm{Fe}(\mathrm{III})$.

\section{Adsorption Capacity of IONPs}

The adsorption capacity of IONPs for peptides and proteins in $5 \mathrm{mM}$ phosphate buffers at $\mathrm{pH} 2$ to 10 was investigated. The amount of analytes adsorbed was determined from the change in analyte concentrations before and after addition of the IONPs into the solutions. Sixty $\mu \mathrm{L}$ of IONPs solution is added to a sample vial. The magnetic particles in the solution were attracted to the bottom of the sample vial by an external magnet, and the supernatant solution was removed by pipet. An aliquot of $1 \mathrm{~mL}$ of $10^{-5} \mathrm{M}$ analyte solution was added. The solution mixture was thoroughly mixed with a shaker for $1 \mathrm{~h}$. After extraction, the magnetic nanoparticles were collected from the solution by using a magnet. Quantitation of the analyte concentrations was performed by a UV-visible spectroscopy (Lambda20; Perkin Elmer, Wellesley, MA) at $409 \mathrm{~nm}$ for myoglobin and at $220 \mathrm{~nm}$ for insulin and angiotensin I.

\section{Sample Preparation and Extraction Procedure}

CHCA and SA solutions, both freshly prepared in 1:1:0.001 acetonitrile/water/TFA solution, were used as the MALDI matrices for peptides and proteins, respectively. Protein and peptide solutions were prepared in deionized water and stored at $-20^{\circ} \mathrm{C}$. MALDI samples were prepared by mixing $1 \mu \mathrm{L}$ of analyte solution and $1 \mu \mathrm{L}$ of matrix solution on the target and letting them dry at room temperature.

Thirty $\mu \mathrm{L}$ of IONPs solution was added to a $1.5 \mathrm{~mL}$ vial. The magnetic particles in the solution were attracted to the bottom of the sample vial by an external magnet, and the supernatant solution was removed by pipet. Then $500 \mu \mathrm{L}$ of peptide or protein solution was added to the sample vial. The mixture was thoroughly mixed with a shaker for $1 \mathrm{~h}$. Again, a magnet was used to isolate the magnetic nanoparticles from the solution after extraction. The isolated magnetic nanoparticles were washed with $100 \mu \mathrm{L}$ of DI water to remove impurities. Then the collected magnetic nanoparticles were deposited on a stainless steel target and allowed to dry. Matrix solution $(1 \mu \mathrm{L})$ was applied on top of the magnetic particles before MALDI MS analysis. Cytochrome $c\left(1.2 \times 10^{-6} \mathrm{M}\right)$ tryptic digestion [30:1 (wt/wt)] was performed in a $25 \mathrm{mM} \mathrm{NH} \mathrm{HCO}_{3}$ buffer solution (pH 7.9) for $24 \mathrm{~h}$ at $37^{\circ} \mathrm{C}$. Before extraction, the digest products were diluted to desired concentration with $\mathrm{NH}_{4} \mathrm{HCO}_{3}$ buffer solution.

In ZipTip pretreatment, a SCX pipet tip (Millipore, MA) containing strong cation exchange resin was first activated by passing through $0.1 \%$ TFA aqueous solution. Then $500 \mu \mathrm{L}$ of peptide or protein solution was passed through the ZipTip. After rinsing two times with $10 \mu \mathrm{L}$ of deionized water, the analytes were eluted with a 0.001:1:1 (vol/vol) TFA-acetonitrile-water mixture $(10 \mu \mathrm{L})$. MALDI samples were prepared by mixing $1 \mu \mathrm{L}$ of elution and $1 \mu \mathrm{L}$ of matrix solution on the target and letting them dry at room temperature.

\section{MALDI-TOF MS}

All the mass spectra were obtained using an Autoflex II (Bruker Daltonics, Bremen, German) time-of-flight mass spectrometer equipped with a $1.22 \mathrm{~m}$ flight tube. The samples were irradiated with a $337 \mathrm{~nm}$ nitrogen laser at $10 \mathrm{~Hz}$. The accelerating voltage was set to $19 \mathrm{kV}$. The laser energy was 40 to $50 \mu \mathrm{J} /$ pulse. All spectra were recorded in the positive linear mode except spectra from the tryptic digestion experiments which were recorded in the positive reflectron mode (flight length $2.6 \mathrm{~m})$.

\section{Results and Discussion}

\section{Adsorption of Peptide and Protein}

IONPs were chosen as the extractors in this study because of their magnetic property and high surface-tovolume ratios, which facilitate the easy isolation of analyte-adsorbed nanoparticles from the sample solution. To prevent nanoparticles aggregation and allow efficient analyte binding, the surface of IONPs was modified with oleate, which contains a carboxylate group and a long carbon chain $\left(\mathrm{C}_{18}\right)$. Oleate molecules may trap positively-charged peptides and proteins through ionic interaction and hydrophobic interaction. To explore the extraction capability of IONPs, both size distribution and analytes adsorption were examined before conducting MS analysis. From the TEM image of IONPs (data not shown), the IONPs were well dispersed and possessed a size distribution of $10.3 \pm 1.3$ $\mathrm{nm}$. The ability of IONPs to extract angiotensin I, insulin, and myoglobin from aqueous solution at different $\mathrm{pH}$ was investigated with UV-VIS absorption spectrometry.ëAsëshownëinëFigureë1,ëtheëamountsëofëthe analytes adsorbed were sensitive to the solution $\mathrm{pH}$. The maximum adsorption occurred at $\mathrm{pH} 4$ for both insulin (curve b) and angiotensin I (curve a), while the maximum adsorption for myoglobin (curve c) was at $\mathrm{pH}$ 6. At the optimal $\mathrm{pH}$, the fractions of analytes that adsorbed to the IONPs were 82,53 , and $70 \%$ for insulin, angiotensin I, and myoglobin, respectively. Based on these results, the adsorption capacity of the IONPs for angiotensin I, insulin, and myoglobin were estimated to be $48 \mathrm{mg} / \mathrm{g}$, $323 \mathrm{mg} / \mathrm{g}$, and $818 \mathrm{mg} / \mathrm{g}$, respectively. The 


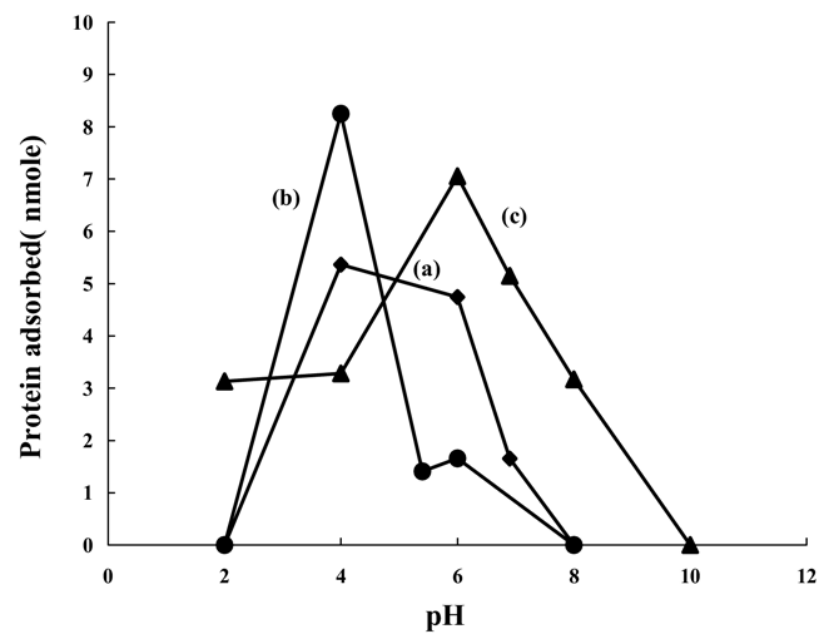

Figure 1. Amounts of (a) angiotensin I, (b) insulin, and (c) myoglobin adsorbed on nanoparticles as a function of solution $\mathrm{pH}$. One $\mathrm{mL}$ of $10^{-5} \mathrm{M}$ analyte solution mixed with $60 \mu \mathrm{L}$ of IONPs solution. The data were made by averaging three measurements from three separate samples. The relative standard deviations of the measurements were less than $10.0 \%$.

isoelectric point (pI) values of angiotensin I, insulin, and myoglobin are 6.9, 5.4, and 6.9, respectively. We found that the maximum adsorption all occurred when the $\mathrm{pH}$ of the protein solution was below the value of $\mathrm{pI}$. At $\mathrm{pH}$ $<\mathrm{pI}$, the protein molecules are positively charged. The pKa value of the oleic acid is around 5.0. The oleic acid dissociates into carboxylate, and the surface of IONPs carries negative charges at $\mathrm{pH}>4$. Therefore, the negatively charged IONPs tend to capture positively charged protein molecules to their surface through electrostatic attraction. When the $\mathrm{pH}$ of the protein solution equals the value of $\mathrm{pI}, 51 \%$ of myoglobin molecules and $15 \%$ of insulin and angiotensin I molecules still attach to the surface of IONPs, even without electrostatic attraction between the protein molecules and IONPs. The adsorption at $\mathrm{pH}=\mathrm{pI}$ indicates that hydrophobic interaction exists between the long carbon chain of oleate and protein molecules. In addition, the hydrogen bonding may also involve in the adsorption process. At $\mathrm{pH}>\mathrm{pI}$, the fraction of protein molecules adsorbed to the IONPs rapidly decrease due to the repulsive force between the negatively charged protein and the negative surface of IONPs. The UV-VIS absorption results suggest that the IONPs can extract peptide and protein molecules from solution through electrostatic attraction, hydrophobic interaction, and hydrogen bonding.

\section{Analysis of Peptides and Proteins by MALDI MS}

To demonstrate mass spectrometric analysis, angiotensin I, insulin, and myoglobin were extracted by IONPs from solution and analyzed using MALDI MS. In our method, the collected analyte-adsorbed IONPs were directly put onto the sample target and $1 \mu \mathrm{L}$ of matrix solution was added. There is no elution step during sample preparation to alleviate sample transfer losses

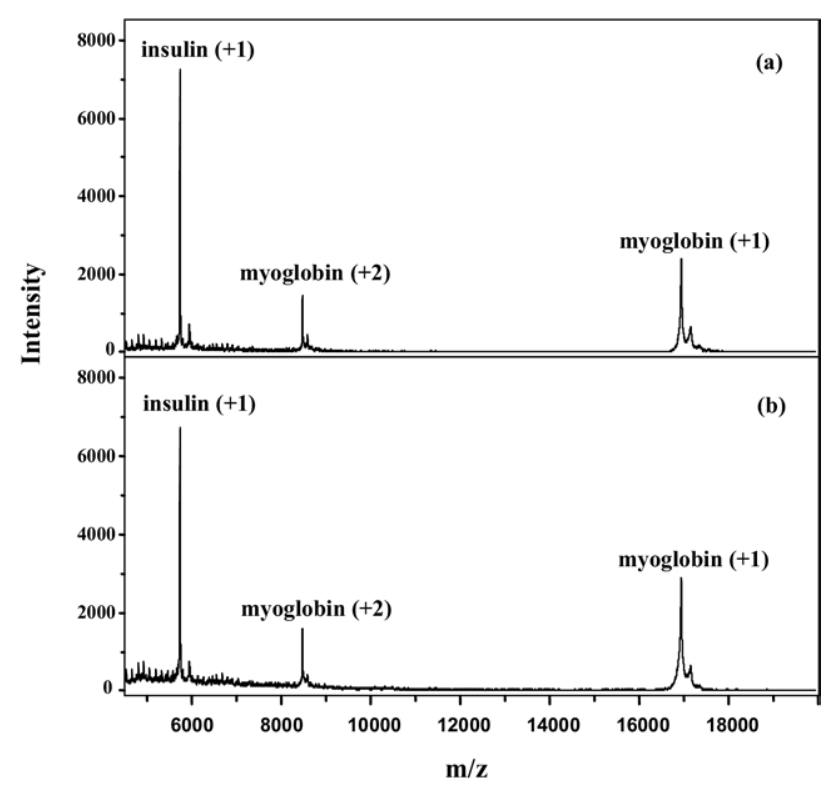

Figure 2. Mass spectra of a protein mixture of insulin $\left(5^{*} 10^{-8} \mathrm{M}\right)$ and myoglobin $\left(1^{*} 10^{-6} \mathrm{M}\right)$ obtained when using IONPs to trap the protein for $1 \mathrm{~h}$. The spectra were obtained (a) without and (b) with removal of the IONPs before MALDI MS analysis. SA was used as the MALDI matrix.

and reduce preparation time. Due to the small size of IONPs, we assumed that the presence of IONPs would not interfere with desorption and ionization process. To demonstrate this assumption, $5 \mu \mathrm{L}$ of $\mathrm{SA}$ solution mixed with the protein-adsorbed IONPs and $1 \mu \mathrm{L}$ of the slurry was used for acquisition of mass spectrum without removal of IONPs. Then the IONPs were collected

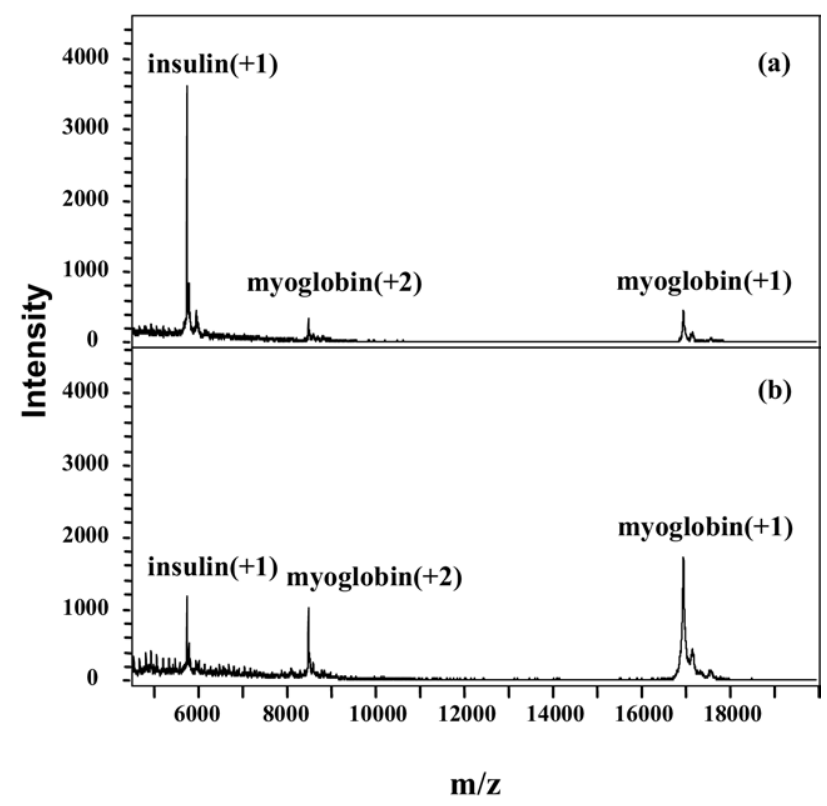

Figure 3. Mass spectra of a protein mixture of insulin $\left(1^{*} 10^{-8} \mathrm{M}\right)$ and myoglobin $\left(1^{*} 10^{-6} \mathrm{M}\right)$ when using IONPs to trap the protein from buffer of different $\mathrm{pH}$ : (a) $\mathrm{pH} 4$, (b) $\mathrm{pH}$ 6, and (c) $\mathrm{pH}$ 10. SA was used as the MALDI matrix. 


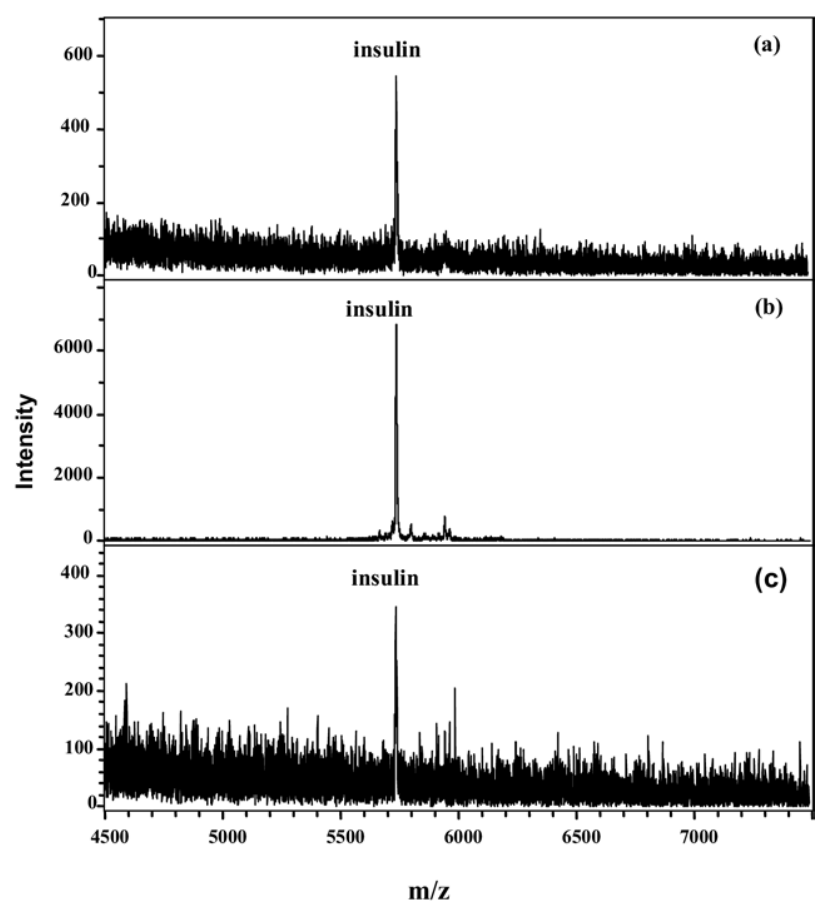

Figure 4. Mass spectra of insulin obtained (a) without any pretreatment, and (b) with preconcentration of $10 \mathrm{nM}$, and (c) 0.1 nMënsulinësolutionëbyëIONPs;ëotherëconditionsëasënëFigureë2.

by a magnet from the remaining $4 \mu \mathrm{L}$ of the slurry and $1 \mu \mathrm{L}$ of the supernatant was analyzed by MALDI MS. Figureęëshowsëheëmassëpectraëffëheёproteinëwithënd without IONPs. There was no distinct difference in these two mass spectra. It suggests that the presence of small IONPs does not deteriorate the signal intensities, resolution, and mass accuracy of the mass spectra as shownëinëFigureë2a.ëInëMALDI,ëtheëreproducibilityëof intra- and inter-sample was usually poor. We also examined the reproducibility of the sample preparation. The signal intensities of angiotensin I, insulin, and myoglobin varied within 2.5 to $11.8 \%$ over 50 sample spots (five samples).

Figureëlëshowsëthatëtheëadsorptionëofëpeptidesëand proteins was significantly affected by the $\mathrm{pH}$ of the solutions. We employed a mixture of insulin and myoglobin to demonstrate the selective capture of protein. From a solution of $\mathrm{pH} \mathrm{4}$, both insulin and myoglobin were captured by IONPs, and the adsorbed proteins wereëconfirmedibyëMALDIëMSë(Figureëßa)ëAtëpHö6,ëhe signal intensity for insulin decreased due to the net negative charges on insulin molecules. However, a fraction of insulin was still adsorbed to IONPs through hydrophobic interaction. From $\mathrm{pH} 4$ to 6 , the signal intensity of myoglobin in the mass spectrum significantlyëincreasedë(Figureë3b),ëwhichëindicatesëhigher adsorption of myoglobin at $\mathrm{pH} 6$. These results were consistentëwithëtheëresultsëobtainedënëFigureël.

The IONPs plays a role as a solid-phase extraction (SPE) support. The increased surface area-to-volume ratio of the particle in comparison to microparticles can allow for efficient extraction and concentration of analytesëfromëveryëdiluteësolution.ëFigureë4aëshowsëthe mass spectrum of insulin $(10 \mathrm{nM})$ without preconcentration process. The signal/noise $(\mathrm{S} / \mathrm{N})$ ratio was determined to be 4.3. No signals were obtained when the insulin concentration was lower than $10 \mathrm{nM}$. With the use of IONPs to preconcentrate the insulin from $500 \mu \mathrm{L}$ of solution, the signal was greatly enhanced with $\mathrm{S} / \mathrm{N}$ ratioëofë63.3ëasëshownëinëFigureë4b.ëComparedëwith regular MALDI, mixing $1 \mu \mathrm{L}$ of analyte solution with 1 $\mu \mathrm{L}$ of matrix solution, the use of IONPs provides a 15 -fold higher peak intensity. With preconcentration by IONPs, the lowest concentration that can be observed wasë0.1ënMë(Figureë4c).ëTheëSCXёZipTip,ëwhichëwould attract positively charged peptide and protein through electrostatic attraction, was also used to preconcentrate insulin from $500 \mu \mathrm{L}$ solution $(10 \mathrm{nM})$. The $\mathrm{S} / \mathrm{N}$ ratio obtained was 20.3. Compared with the ZipTip result, the signal intensity obtained by the use of IONPs was more than three times larger. The same experiments were performed for myoglobin and angiotensin I, and theëresultsëareësummarizedëinë Tableë1.ë Theëresults indicate that the signal enhancements for the three analytes are 2- to 3-fold higher when compared to those with ZipTip. In addition, ZipTip requires more sample manipulation and increases the possibility of contamination or sample loss. With preconcentration by IONPs, the lowest detectable concentrations of myoglobin and angiotensin I were $10.0 \mathrm{nM}$ and $0.1 \mathrm{nM}$.

\section{Mass Analysis of Peptide and Protein in Complex Sample Solution}

Samples from biological sources often contain a complex mixture of salts and surfactants. However, the presence of these contaminants will suppress the analyte signals in MALDI MS. We investigated the ability of using IONPs to capture analytes and eliminate the interference from high concentration of salts or surfactants.ËFigureēaëshowsëheëmassëpectrumëofënsulinënd myoglobin mixture in a sample solution containing $0.1 \%$ SDS. Only a very weak signal was observed for

Table 1. The signal-to-noise ratios of analytes without and with preconcentration by IONPs and ZipTip

\begin{tabular}{lccr}
\hline \multicolumn{1}{c}{ Analytes } & Without pretreatment & Preconcentration by IONPs & Preconcentration by ZipTip \\
\hline \hline Angiotensin I & 3.8 & 32.4 & 13.6 \\
Insulin $^{\mathrm{a}}$ & 4.3 & 63.3 & 20.3 \\
Myoglobin $^{\mathrm{a}}$ & 9.6 & 68.9 & 26.9 \\
\hline
\end{tabular}

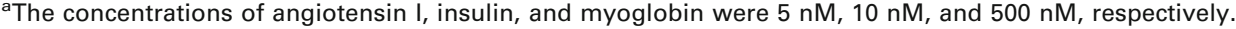



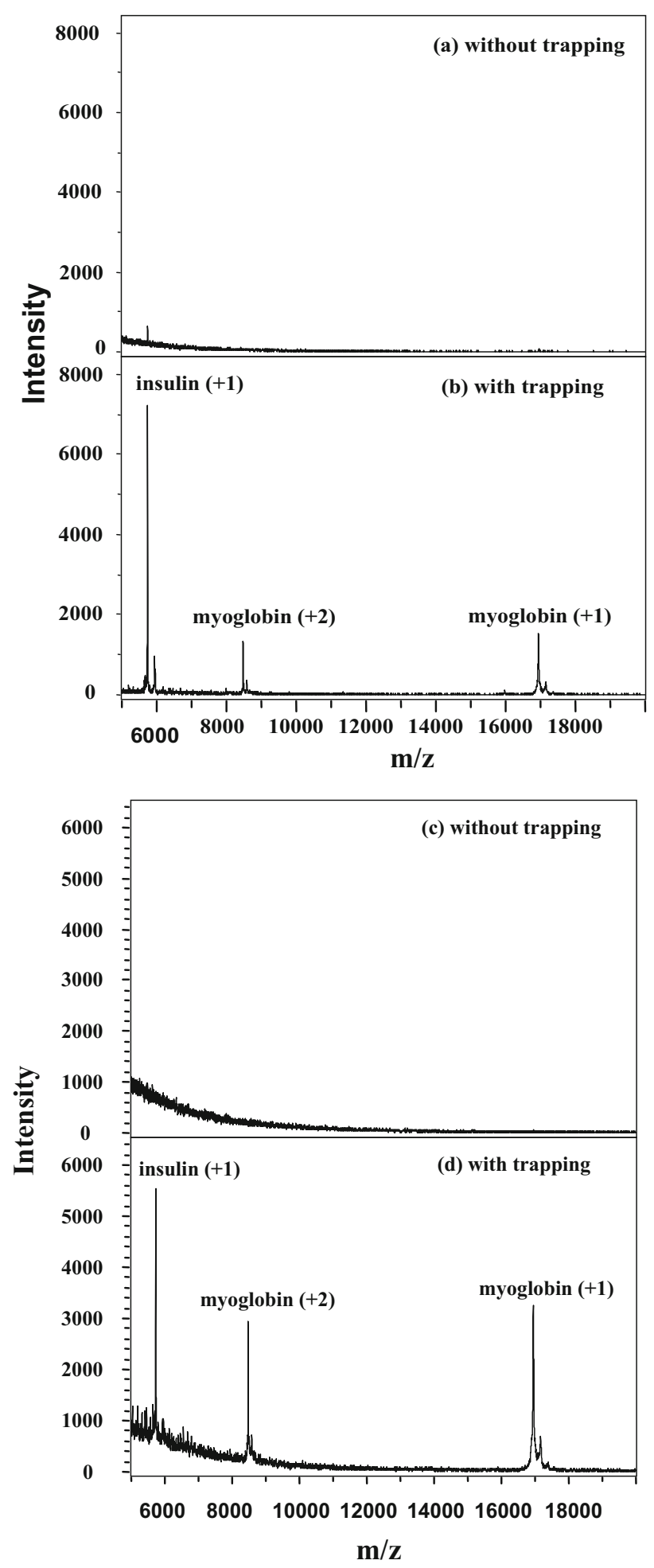

Figure 5. Mass spectra of insulin and myoglobin solution containing $0.1 \%$ SDS obtained (a) without any pretreatment, and (b) with extraction of mixture solution by IONPs. Mass spectrum of insulin and myoglobin solution containing $8 \mathrm{M}$ urea obtained (c) without any pretreatment, and (d) with extraction of mixture solutionëbyëIONPs;ëotherëconditionsëasënëFigureë2.

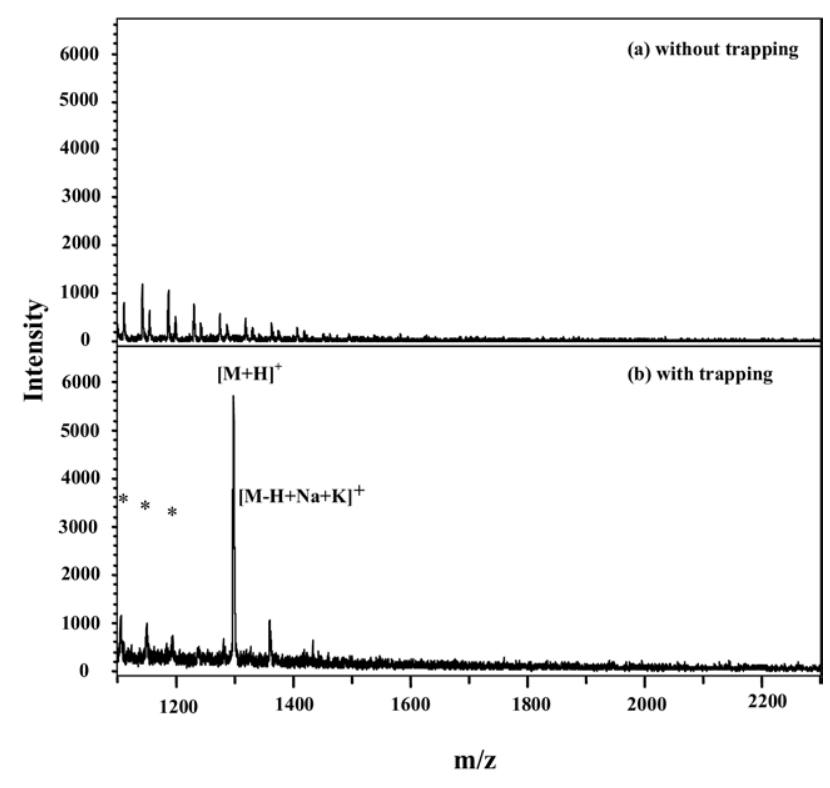

Figure 6. Mass spectrum of angiotensin I solution containing 20\% TritonX-100 obtained (a) without any pretreatment, and (b) with extraction of mixture solution by IONPs. CHCA was used as the MALDI matrix.

insulin, and no myoglobin ion was detected. When using IONPs to extract insulin and myoglobin from a solution mixture containing $0.1 \%$ SDS, the intense signalsêforèbothënsulinëndëmyoglobinëvereëpresentënëthe massëspectrumë(Figureë $5 b)$.ëUreaëisëalsoëfrequently foundënëproteinësampleësolutions.ëFigureēcëshowsëthe mass spectrum of insulin and myoglobin mixture in a sample solution containing $8 \mathrm{M}$ urea. No insulin or myoglobin ion was detected. When using IONPs to extract insulin and myoglobin from a solution mixture containing $8 \mathrm{M}$ urea, the intense signals for both insulin and myoglobin were present in the mass spectrum (Figureë5d).ëTheëuseëofëIONPsëenhancedëtheësignal intensities in the presence of the contaminations; however, the signal intensities were still lower compared with the analyte solutions of same concentration without salts or surfactants.

The presence of TritonX-100, a nonionic surfactant, in MALDI samples usually degrades analyte signal. Figureë6aëshowsëtheëmassëspectrumëofëangiotensinël containing 20\% TritonX-100. No angiotensin I ion was detected except a series of TritonX-100 cluster ions appearedënëtheëmassëspectrum.ëFigureë6bëshowsëthe mass spectrum of angiotensin I after IONPs extraction. The angiotensin I ion was detected at $\mathrm{m} / \mathrm{z}$ 1297.67, and the signal at $\mathrm{m} / \mathrm{z} 1359.40$ corresponded to $[\mathrm{M}-\mathrm{H}+\mathrm{Na}+\mathrm{K}]^{+}$. Those peaks marked with asterisks were generated from TritonX-100. Although slight amount of TritonX-100 was adsorbed onto the IONPs through hydrophobic interaction, the angiotensin I could be efficiently isolated from sample solution by using IONPs. These results demonstrate that the analytes can be extracted from contaminated sample solution by using IONPs and the interference 


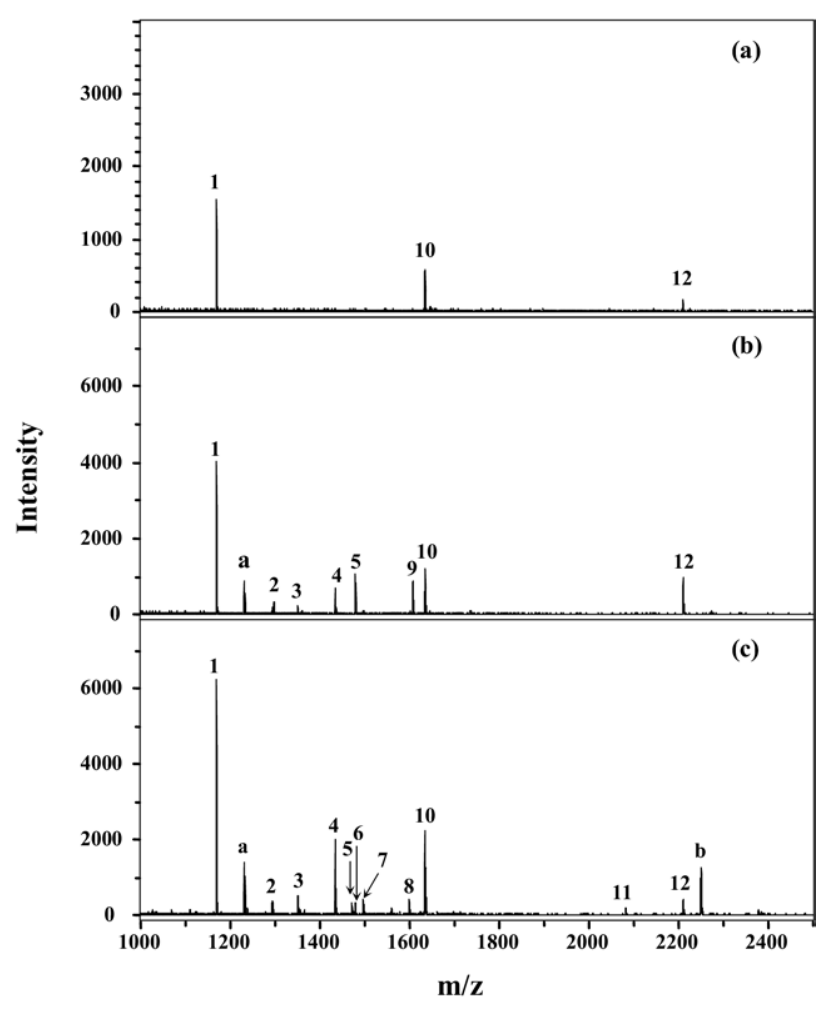

Figure 7. Mass spectrum of the tryptic digest products of cytochrome $c$ obtained (a) without preconcentration, (b) with preconcentration of the digest products $(50 \mu \mathrm{L})$ by IONPs, and (c) with preconcentration of cytochrome $c(500 \mu \mathrm{L})$, followed by onparticle enzymatic digestion. CHCA was used as the MALDI matrix.ëPeakëdentitiesëareëlistedënëTableë2.

of salts and surfactants can be minimized. This developed procedure provides cleaning and concentration at the same time.

\section{Mass Analysis of Enzymatic Digest Products}

The applicability of the method for analyzing tryptic digestëproductsëofëcytochromeëc wasënvestigated.ëFigureë 7aë showsë theë massë spectrumë ofë cytochromeë $c$ $\left(2.5^{*} 10^{-7} \mathrm{M}\right)$ tryptic digest products without trapping by IONPs. There were three low-intensity signals in the massëspectrum.ëFigureë’bëshowsëtheëmassëspectrumëof cytochrome $c$ tryptic digest products $\left(5^{*} 10^{-8} \mathrm{M}, 50 \mu \mathrm{L}\right)$ after using IONPs to capture the peptide fragments of digest products. More intense peaks appeared in the mass spectrum. The ions at $\mathrm{m} / \mathrm{z} 1168.64,1296.74$, $1350.72,1433.82,1478.86,1606.97,1633.69$, and 2209.19 correspond to the enzymatic digest products of cytochrome $c$, and were confirmed by protein NCBI database searches. The probability-based Mowse score was 126. Signals were enhanced without the need to preseparate the enzyme and IONPs from the peptide fragments for MALDI MS analysis. In another important application, IONPs were used to preconcentrate low concentration of cytochrome $c$, and the enzymatic digestion of cytochrome $c$ was conducted directly on the particles. An aliquot of $500 \mu \mathrm{L}$ cytochrome $c$ solution $\left(5^{*} 10^{-8} \mathrm{M}\right)$ mixed with $10 \mu \mathrm{L}$ of IONPs for $1 \mathrm{~h}$. A magnet was used to collect the IONPs, and the supernatant was removed by a pipet. Trypsin in $\mathrm{NH}_{4} \mathrm{HCO}_{3}$ buffer solution $(2.5 \mu \mathrm{L}, 20 \mathrm{ng} / \mu \mathrm{L})$ was added to mix with the cytochrome $c$-adsorbed IONPs. The mixture reacted for $24 \mathrm{~h}$ at $37^{\circ} \mathrm{C}$. A magnet was used again to collect the peptide-adsorbed IONPs, followed by MALDI analysis. The mass spectrum of on-particle trypticëdigestëffëytochromeë isëhownënت̈Figureäc.ëThe ions at $\mathrm{m} / \mathrm{z} 1168.67,1296.72,1350.79,1433.85,1470.74$, $1478.88,1495.77,1598.84,1633.69,2081.04$, and 2209.14 correspond to the enzymatic digest products of cytochrome $c$, and were matched by protein NCBI database searches with a probability-based Mowse score of 170 . Tableë2ëlistsëtheëdetailedëaminoëacidësequence.ëPeakëa $(\mathrm{m} / \mathrm{z}=1230.58)$ and peak $\mathbf{b}(\mathrm{m} / \mathrm{z}=2248.97)$ were not matched by NCBI database searches. Peak a may be caused by the impurity of sample. Peak $b$ was assigned to be the incomplete digestion fragment, because the cleavage site on cytochrome $c$ may be blocked by the adsorption of cytochrome $c$ on the IONPs. This method integrates isolation, concentration, purification, and digestion on nanoparticles. Compared with the concen-

Table 2. Ions observed in the MALDI mass spectrum of cytochrome $c$ tryptic digest and a comparison with the output of the NCBI database

\begin{tabular}{|c|c|c|c|c|}
\hline Peak no. & Observed $\mathrm{m} / \mathrm{z}$ & Start-end sequence & Miss $^{a}$ & Peptide sequence \\
\hline 1 & 1168.67 & $28-38$ & 0 & TGPNLHGLFGR \\
\hline 2 & 1296.72 & $28-39$ & 1 & TGPNLHGLFGRK \\
\hline 3 & 1350.79 & $89-99$ & 1 & TEREDLIAYLK \\
\hline 4 & 1433.85 & $26-38$ & 1 & HKTGPNLHGLFGR \\
\hline 5 & 1470.74 & $40-53$ & 0 & TGQAPGFTYTDANK \\
\hline 6 & 1478.88 & $89-100$ & 2 & TEREDLIAYLKK \\
\hline 7 & 1495.77 & $61-72$ & 0 & EETLMEYLENPK \\
\hline 8 & 1598.84 & $39-53$ & 1 & KTGQAPGFTYTDANK \\
\hline 9 & 1606.97 & $88-100$ & 3 & KTEREDLIAYLKK \\
\hline 10 & 1633.69 & $9-22$ & 1 & IFVOKCAQCHTVEK \\
\hline 11 & 2081.04 & $56-72$ & 1 & GITWKEETLMEYLENPK \\
\hline 12 & 2209.14 & $56-73$ & 2 & GITWKEETLMEYLENPKK \\
\hline
\end{tabular}

aNumber of missed cleavages. 
tration typically used in tryptic digestion for peptide mapping, the concentration of cytochrome $c$ used in this experiment is lower by two orders of magnitude.

\section{Conclusions}

We prepared iron oxide nanoparticles modified with oleate and used them as SPE support to concentrate peptide and protein from dilute solution. With preconcentration, the lowest detectable concentration of angiotensin I, insulin, and myoglobin were $0.1 \mathrm{nM}, 0.1 \mathrm{nM}$, and $10 \mathrm{nM}$, respectively. Sensitivity may be further enhanced by using a larger volume of sample solution and a longer extraction time. In addition, the use of IONPs can eliminate the suppression of analyte signals due to salts and surfactants in MALDI samples. We have successfully applied the developed method to the analysis of enzymatic digest products of proteins. In the future, the modification of the iron oxide nanoparticle surfaces can be developed to achieve selective capture of target biomolecules.

\section{Acknowledgments}

The authors gratefully acknowledge financial support from the National Science Council of Taiwan.

\section{References}

1. Hillenkamp, F.; Karas, M.; Beavis, R. C.; Chait, B. T. Matrix-Assisted Laser Desorption/Ionization Mass Spectrometry of Biopolymers. Anal. Chem. 1991, 63, 1193A-1202A.

2. Fenselau, C.; Demirev, P. A. Characterization of Intact Microorganisms by MALDI Mass Spectrometry. Mass Spectrom. Rev. 2001, 20, 157-171.

3. Karas, M.; Hillenkamp, F. Laser Desorption Ionization of Proteins with Molecular Masses Exceeding 10,000 Daltons. Anal. Chem. 1988, 60, 2299-2301.

4. Brown, R. S.; Lennon, J. J. Mass Resolution Improvement by Incorporation of Pulsed Ion Extraction in a Matrix-Assisted Laser Desorption/ Ionization Linear Time-of-Flight Mass Spectrometer. Anal. Chem. 1995, 67, 1998-2003.

5. Vestal, M. L.; Jusahz, P.; Martin, S. A. Delayed Extraction MatrixAssisted Laser Desorption Time-of-Flight Mass Spectrometry. Rapid Commun. Mass Spectrom. 1995, 9, 1044-1050.

6. Xu, Y.; Bruening, M. L.; Watson, S. R. Nonspecific, On-probe Cleanup Methods for MALDI-MS Samples. Mass Spectrom. Rev. 2003, 22, $429-$ 440 .

7. Tang, N.; Tornatore, P.; Weinberger, S. R. Current Developments in SELDI Affinity Technology. Mass Spectrom. Rev. 2004, 23, 34-44.

8. Issaq, H. J.; Conrads, T. P.; Prieto, D. A.; Tirumalai, R.; Veenstra, T. D. SELDI-TOF MS for Diagnostic Proteomics. Anal. Chem. 2003, 75, 149A155A.

9. Issaq, H. J.; Veenstra, T. D.; Conrads, T. P.; Felschow, D. The SELDI-TOF MS Approach to Proteomics: Protein Profiling and Biomarker Identification. Biochem. Biophys. Res. Commun. 2002, 292, 587-592.

10. Brockman, A. H.; Shah, N. N.; Orlando, R. Optimization of a Hydrophobic Solid-Phase Extraction Interface for Matrix-Assisted Laser Desorption/Ionization. J. Mass Spectrom. 1998, 33, 1141-1147.

11. Brockman, A. H.; Dodd, B. S.; Orlando, R. A Desalting Approach for MALDI-MS Using On-probe Hydrophobic Self-Assembled Monolayers. Anal. Chem. 1997, 69, 4716-4720.

12. Xu, Y.; Watson, T.; Bruening, M. L. Patterned Monolayer Polymer Films for Analysis of Dilute or Salt-Contaminated Protein Samples by MALDI-MS. Anal. Chem. 2003, 75, 185-190.

13. Warren, M. E.; Brockman, A. H.; Orlando, R. On-Probe Solid-Phase Extraction/MALDI-MS Using Ion-pairing Interactions for the Cleanup of Peptides and Proteins. Anal. Chem. 1998, 70, 3757-3761.

14. Brockman, A. H.; Orlando, R. Probe-Immobilized Affinity Chromatography/Mass Spectrometry. Anal. Chem. 1995, 67, 4581-4585.

15. Liang, X.; Lubman, D. M.; Rossi, D. T.; Nordblom, G. D.; Barksdale, C. M. On-Probe Immunoaffinity Extraction by Matrix-Assisted Laser Desorption Ionization Mass Spectrometry. Anal. Chem. 1998, 70, 498503.
16. Hutchens, T. W.; Yip, T. New Desorption Strategies for the Mass Spectrometric Analysis of Macromolecules. Rapid Commun. Mass Spectrom. 1993, 7, 576-580.

17. Gevaert, K.; Demol, H.; Sklyarova, T.; Vandekerckhove, J.; Houthaeve, T. A Peptide Concentration and Purification Method for Protein Characterization in the Subpicomole Range Using Matrix Assisted Laser Desorption/Ionization-Postsource Decay (MALDI-PSD) Sequencing. Electrophoresis 1998, 19, 909-917.

18. Gevaert, K.; Demol, H.; Puype, M.; Broekaert, D; Boeck, S. D. Houthaeve, T.; Vandekerckhove, J. Peptides Adsorbed on ReversePhase Chromatographic Beads as Targets for Femtomole Sequencing by Postsource Decay Matrix Assisted Laser Desorption Ionization-Reflectron Time of Flight Mass Spectrometry (MALDI-RETOF-MS). Electrophoresis 1997, 18, 2950-2960.

19. Papac, D. I.; Hoyes, J.; Tomer, K. B. Direct Analysis of Affinity-Bound Analytes by MALDI/TOF MS. Anal. Chem. 1994, 66, 2609-2613.

20. Zhou, W.; Merrick, B. A.; Khaledi, M. G.; Tomer, K. B. Detection and Sequencing of Phosphopeptides Affinity Bound to Immobilized Metal Ion Beads by Matrix-Assisted Laser Desorption/Ionization Mass Spectrometry. J. Am. Soc. Mass Spectrom. 2000, 11, 273-282.

21. Paska, C. S.; Parker, C. E.; Dominski, Z.; Marzluff, W. F.; Glish, G. L. Pope, R. M.; Borchers, C. H. Direct MALDI-MS/MS of Phosphopeptides Affinity-Bound to Immobilized Metal Ion Affinity Chromatography Beads. Anal. Chem. 2002, 74, 3429-3433.

22. Girault, S.; Chassaing, G.; Blais, J. C.; Bolbach, G. Coupling of MALDITOF Mass Analysis to the Separation of Biotinylated Peptides by Magnetic Streptavidin Beads. Anal. Chem. 1996, 68, 2122-2126.

23. Villanueva, J.; Philip, J.; Entenberg, D.; Chaparro, C. A.; Tanwar, M. K.; Holland, E. C.; Tempst, P. Serum Peptide Profiling by Magnetic Particle-Assisted, Automated Sample Processing and MALDI-TOF Mass Spectrometry. Anal. Chem. 2004, 76, 1560-1570.

24. Yaneva, M.; Tempst, P. Affinity Capture of Specific DNA-Binging Proteins for Mass Spectrometric Identification. Anal. Chem. 2003, 75, 6437-6448.

25. Brockman, A. H.; Orlando, R. Probe-Immobilized Affinity Chromatography/Mass Spectrometry. Anal. Chem. 1995, 67, 4581-4585.

26. Schriemer, D. C.; Li, L. Combining Avidin-Biotin Chemistry with Matrix-Assisted Laser Desorption/Ionization Mass Spectrometry. Anal. Chem. 1996, 68, 3382-3387.

27. Turney, K.; Drake, T. J.; Smith, J. E.; Tan, W.; Harrison, W. W. Functionalized Nanoparticles for Liquid Atmospheric Pressure MatrixAssisted Laser Desorption/Ionization Peptide Analysis. Rapid Commun. Mass Spectrom. 2004, 18, 2367-2374.

28. Tseng, C.-H.; Ho, K.-C.; Lin, Y.-S.; Chen, Y.-C. Gold Nanoparticles as Selective and Concentrating Probes for Samples in MALDI MS Analysis. Anal. Chem. 2004, 76, 4337-4342.

29. Kong, X. L.; Huang, L. C. L.; Hsu, C.-M.; Chen, W.-H.; Han, C.-C.; Chang, H.-C. High-Affinity Capture of Proteins by Diamond Nanoparticles for Mass Spectrometric Analysis. Anal. Chem. 2005, 77, 259-265.

30. Chen, C.-T.; Chen, Y.-C. $\mathrm{Fe}_{3} \mathrm{O}_{4} / \mathrm{TiO}_{2}$ Core/Shell Nanoparticles as Affinity Probes for the Analysis of Phosphopeptides Using $\mathrm{TiO}_{2}$ Surface-Assisted Laser Desorption/Ionization Mass Spectrometry. Anal. Chem. 2005, 77, 5912-5919.

31. Zhang, Y.; Yu, X.; Wang, X.; Shan, W.; Yang, P.; Tang, Y. Zeolite Nanoparticles with Immobilized Metal Ions: Isolation and MALDITOF-MS/MS Identification of Phosphopeptides. Chem. Commun. 2004, 2882-2883.

32. Lin, P.-C.; Chou, P.-H.; Chen, S.-H.; Liao, H.-K.; Wang, K.-Y.; Chen, Y.-J., Lin, C.-C. Ethylene Glycol-Protected Magnetic Nanoparticles for a Multiplexed Immunoassay in Human Plasma. small No. 4, 2006, 2, 485-489.

33. Chou, P.-H.; Chen, S.-H.; Liao, H.-K.; Lin, P.-C.; Her, G.-R.; Lai, A. C.-Y. Chen, J.-H.; Lin, C.-C.; Chen, Y.-J. Nanoprobe-Based Affinity Mass Spectrometry for Selected Protein Profiling in Human Plasma. Anal. Chem. 2005, 77, 5990-5997.

34. Flad, T.; Schiestel, T.; Brunner, H. Tolson, J; Ouyang Q : Pawelec, G.; Mueller, G. A.; Mueller, C. A.; Tovar, G. E. M.; Beck, H. Development of an MHC-Class I Peptide Selection Assay Combining Nanoparticle Technology and Matrix-Assisted Laser Desorption/Ionization Mass Spectrometry. J. Immunol. Methods 2003, 283, 205-213.

35. Maier, M.; Fritz, H.; Gerster, M.; Schewitz, J.; Bayer, E. Quantitation of Phosphorothioate Oligonucleotides in Human Blood Plasma Using a Nanoparticle-Based Method for Solid-Phase Extraction. Anal. Chem 1998, 70, 2197-2204.

36. Kong, X.; Huang, L. C. L.; Liau, S.-C. V.; Han, C.-C.; Chang, H.-C Polylysine-Coated Diamond Nanocrystals for MALDI-TOF Mass Analysis of DNA Oligonucleotides. Anal. Chem. 2005, 77, 4273-4277.

37. Huang, Y.-F.; Chang, H.-T. Nile Red-Adsorbed Gold Nanoparticle Matrixes for Determining Aminothiols Through Surface-Assisted Laser Desorption/Ionization Mass Spectrometry. Anal. Chem. 2006, 78, 14851493.

38. Chan, W.-Y.; Wang, L.-S.; Chiu, H.-T.; Chen, Y.-C. Carbon Nanotubes as Affinity Probes for Peptides and Proteins in MALDI MS Analysis. J. Am. Soc. Mass Spectrom. 2004, 15, 1629-1635.

39. Weber, A.; Borchers, K.; Schmucker, J.; Brunner, H.; Tovar, G. E. M. Protein-Microarray Constituted from Streptavidin-Coated Nanoparticles Deposited via Poly9electrolyte) Multilayers for Analysis of Biotinylated Ligands by MALDI Mass Spectrometry and Fluorescence Imaging. Can. J. Anal. Sci. Spectrom. 2005, 50, 49-53. 
40. Ho, K.-C.; Tsai, P.-J.; Lin, Y.-S.; Chen, Y.-C. Using Biofunctionalized Nanoparticles to Probe Pathogenic Bacteria. Anal. Chem. 2004, 76, $7162-7168$.

41. Lin, Y.-S.; Tsai, P.-J.; Weng, M.-F.; Chen, Y.-C. Affinity Capture Using Vancomycin-Bound Magnetic Nanoparticles for the MALDI-MS Analysis of Bacteria. Anal. Chem. 2005, 77, 1753-1760.

42. Huang, L.-C. L.; Chang, H.-C. Adsorption and Immobilized of Cytochrome $c$ on Nanodiamonds. Langmuir 2004, 20, 5879-5884.

43. Kang, Y. S.; Risbud, S.; Rabolt, J. F.; Stroeve, P. Synthesis and Characterization of Nanometer-Size $\mathrm{Fe}_{3} \mathrm{O}_{4}$ and $\gamma-\mathrm{Fe}_{2} \mathrm{O}_{3}$ Particles. Chem. Mater. 1996, 8, 2209-2211.
44. Kang, Y. S.; Lee, D. K.; Lee C. S. In Situ Observation of Domain Structure in Monolayer of Arachidic Acid/ $\gamma-\mathrm{Fe}_{2} \mathrm{O}_{3}$ Nanoparticle Complexes at the Air/Water Interface. J. Phys. Chem. B 2002, 106, 9341-9346.

45. Kim, D. K.; Mikhaylova, M.; Zhang Y.; Muhammed, M. Protective Coating of Superparamagnetic Iron Oxide Nanoparticles. Chem. Mater. 2003, 15, 1617-1627.

46. Kim, D. K.; Zhang, Y.; Voit, W.; Rao, K. V.; Muhammed, M. Synthesis and Characterization of Surfactant-Coated Superparamagnetic Monodispersed Iron Oxide Nanoparticles. J. Magn. Magn. Mater. 2001, 225, 30-36. 